\title{
Hubungan antara Indeks Massa Tubuh dan Jumlah CD4 pada Penderita HIV yang Mendapat Pengobatan ARV
}

\author{
Miftahurachman, ${ }^{1}$ Rudi Wisaksana ${ }^{2}$ \\ ${ }^{1}$ Divisi Endokrinologi \& Metabolisme, Departemen Ilmu Penyakit Dalam Fakultas Kedokteran Universitas \\ Padjadjaran/Rumah Sakit Dr. Hasan Sadikin Bandung, ${ }^{2}$ Divisi Penyakit Tropik dan Infeksi, Departemen Ilmu \\ Penyakit Dalam Fakultas Kedokteran Universitas Padjadjaran/Rumah Sakit Dr. Hasan Sadikin Bandung
}

\begin{abstract}
Abstrak
Efek merugikan obesitas pada populasi umum dalam hubungannya dengan mortalitas dan morbiditas untuk terjadi penyakit kardiovaskular telah diketahui dengan baik, namun pada penderita HIV hubungan berat badan dengan morbiditas dan mortalitas penyakit tersebut masih perlu dikaji lebih lanjut. Penelitian ini bertujuan mencari hubungan antara IMT dan CD4. Uji potong lintang dengan pendekatan deskriptif analitik dari data sekunder rekam medik penderita HIV yang berobat ke poliklinik Teratai RSUP Dr. Hasan Sadikin Bandung pada tahun 2007-2011. Variabel yang diteliti adalah IMT dan jumlah CD4 (p=0,0001) dengan uji korelasi Spearman dan uji Kruskal Wallis. Dari 936 penderita HIV rata-rata IMT 19,4 dan jumlah CD4 rata-rata $151 \mathrm{sel} / \mathrm{mm}^{3}$. Terdapat hubungan positif antara IMT dengan nilai CD4, dengan kekuatan hubungan kategori sedang $(r=0,409)$. Dengan mengkategorikan IMT, didapatkan perbedaan rata-rata CD4 antara keempat kategori IMT tersebut $(p=0,0001)$, nilai CD4 rata-rata dan rentangnya dari yang terendah sampai yang tertinggi berturut-turut: underweight: 75 (1-1.329), normoweight: 229 (4-1.047), overweight: 259 (2-1.275), obese: 447 (71-654). Peningkatan IMT berhubungan dengan peningkatan jumlah CD4, menggambarkan penurunan morbiditas, mortalitas serta risiko progresivitas HIV. [MKB. 2015;47(4):237-41]
\end{abstract}

Kata kunci: CD4, HIV, indeks massa tubuh (IMT)

\section{Correlation between Body Mass Index and CD4 Level in HIV Patients with Antiretroviral Therapy}

The adverse consequence of overweight and obese condition in major population related to it's mortality and morbidity of specific diseases like coronary heart disease has been well known. However, in immunocompromised patients, in the context of body weight with it's morbidity and mortality needs further examination. The objective of this research was to find out the relationship between BMI and CD4 level, which describes disease progressivity from HIV patients whom already had antiretroviral (ARV) therapy. We conducted cross sectional method with descriptive analytic from secondary data of medical records from HIV patients who came to Teratai Polyclinic of Hasan Sadikin General Hospital Bandung from 2007 to 2011. From 936 HIV patients analyzed, median BMI was 19,4 with range between $12.1-36.2 \mathrm{~kg} / \mathrm{m}^{2}$, median CD4 was 151 cells $/ \mathrm{mm}^{3}$ with range between $1-1,329$. The $\mathrm{r}$ value was 0.409 , suggested positive correlation significance between BMI and CD4 value, CD4 value increased parallel with the increasing of BMI, with intermediate $\mathrm{p}$ value $(\mathrm{p}=0.0001)$. Since we categorized BMI, the median of CD4 between all categories ( $\mathrm{p}=0.0001)$, range from the smallest to the highest was underweight:75 (1-1,329), normoweight: 229 (4-1,047), overweight: 259 (2-1,275), obese: 447 (71-654) cells $/ \mathrm{mm}^{3}$, respectively. As conclusion, increasing of BMI related to enhancement of CD4 level, suggests reduction of HIV morbidity and mortality. [MKB. 2015;47(4):237-41]

Key words: Body mass index (BMI), CD4, HIV

Korespondensi: Miftahurachman, dr., Sp PD., M. Kes, Departemen Ilmu Penyakit Dalam Fakultas Kedokteran Universitas Padjadjaran/Rumah Sakit Dr. Hasan Sadikin Bandung, Jalan Pasteur No. 38 Bandung, mobile 08156049792, e-mail miftahrachman@yahoo.com 


\section{Pendahuluan}

Efek merugikan berat badan lebih atau obesitas pada populasi umum dalam hubungannya dengan mortalitas dan juga morbiditas terjadi penyakit spesifik seperti penyakit jantung koroner telah diketahui dengan baik. Dalam situasi tertentu, penambahan berat badan mampu memberikan efek yang menguntungkan. Beberapa penelitian yang sudah dipublikasikan mendapatkan hasil peningkatan angka harapan hidup dengan penambahan jumlah berat badan atau obesitas, misalnya pada keadaan gagal ginjal kronik dan infeksi HIV yang merupakan dua kondisi yang ditandai dengan gangguan sistem imun. Penelitian "The Miami Intravenous Drug Abuse Study/MIDAS" menemukan bahwa peningkatan indeks massa tubuh (IMT) berhubungan dengan penurunan mortalitas penderita dengan HIV positif baik pada laki-laki ataupun perempuan. Penelitian ini telah mendapatkan penurunan risiko untuk terjadi risiko berkurangnya jumlah CD4 sebesar 25\% pada subjek penelitian dengan keadaan yang obesitas. Penelitian Shuter dkk. ${ }^{1}$ melaporkan penurunan progresivitas HIV pada subjek laki-laki dan perempuan obes, walaupun jumlah CD4 awal dan waktu yang sama pada saat memulai terapi antiretroviral (ARV) yang dibanding dengan pasien yang tidak overweight.

Penelitian The Nutrition for Healthy Living Study/NFHL, memakai impendansi bioelektrikal untuk mengukur komposisi tubuh, menemukan bahwa IMT berkorelasi erat dengan massa lemak pada penderita HIV perempuan. Penelitian ini juga mendapatkan efek protektif dari massa lemak terhadap progresivitas penderita HIV perempuan (penurunan jumlah CD4) pada analisis multivariat, tetapi tidak berhubungan dengan penurunan angka mortalitas. ${ }^{2-3}$

Dari pemaparan di atas, diperlukan penelitian mengenai hubungan antara IMT dan CD4 (yang menggambarkan progresivitas penyakit) pada penderita HIV yang berobat ke Poliklinik Teratai Rumah Sakit Dr. Hasan Sadikin Bandung yang juga dihubungkan dengan mortalitas penderita tersebut. Data yang didapatkan ini diharapkan dapat memberikan informasi hubungan antara IMT dan jumlah CD4 pada penderita HIV yang berobat ke Poliklinik Teratai Rumah Sakit Dr. Hasan Sadikin Bandung.

\section{Metode}

Metode penelitian yang dipergunakan adalah uji potong lintang dengan pendekatan deskriptif analitik dari data sekunder rekam medik para penderita HIV yang berobat ke poliklinik Teratai RS Dr. Hasan Sadikin Bandung pada tahun 20072011 yang telah mendapat pengobatan ARV. Variabel yang diteliti adalah IMT dan jumlah CD4 dengan uji korelasi Spearman dan uji Kruskal Walis untuk menguji hubungan kedua variabel tersebut.

Indeks masa tubuh (IMT) dihitung dengan menggunakan rumus berat badan (kilogram)/ tinggi badan ${ }^{2}$ (meter). Indeks masa tubuh (IMT) pada penelitian ini juga dianalisis berdasarkan pengelompokan dari Western Pacific Region of WHO Criteria Pertaining to Obesity (WPRO criteria, 2000) yaitu underweight (IMT <18,5), normoweight IMT 18,5-22,9), overweight (IMT 23-24,9), obese I $(25-29,9)$ dan obese II (IMT $\geq 30$ ). ${ }^{4}$ CD4 (jumlah sel $/ \mathrm{mm}^{3}$ ) dianalisis dengan flow cytometry dan dianalisis sebagai variabel kontinu di dalam mencari hubungannya dengan IMT.

\section{Hasil}

Karakteristik subjek penelitian dapat dilihat pada Tabel 1. Hasil analisis menggunakan uji korelasi Spearman, didapatkan nilai $\mathrm{p}=0,0001$ $(p<0,05)$ dengan nilai $r$ Spearman $=0,409$, hal ini menunjukkan hubungan positif antara IMT dan CD4, jika nilai IMT semakin besar maka semakin besar pula nilai CD4 (dengan kekuatan hubungan kategori sedang). Hubungan tersebut juga dapat dilihat pada Gambar 1. Hubungan antara IMT dan CD4 dengan pengategorian IMT dapat dilihat pada Tabel 3. Dengan mengkategorikan IMT dari hasil analisis menggunakan uji Kruskal Wallis maka diperoleh perbedaan CD4 rata-rata (median) antara keempat kategori IMT tersebut ( $p=0,0001)$. Nilai (median) CD4 rata-rata dengan rentang dari yang paling rendah sampai dengan yang paling tinggi berturut-turut underweight 75 (1-1.329), normoweight: 229 (4-1.047), overweight: 259 (2-1.275), obese: 447 (71-654). Untuk lebih jelasnya dapat dilihat pada Gambar 2. Dari Gambar 2 dapat dilihat bahwa semakin tinggi kategori IMT semakin besar nilai median CD4 yang didapatkan.

Pada penelitian ini juga dianalisis hubungan status penderita HIV, baik yang masih hidup (aktif berobat di RSHS atau ditransfer ke pusat pelayanan pengobatan lain) maupun yang sudah meninggal, dengan IMT dan CD4-nya. Hubungan tersebut dapat dilihat pada Tabel 4.

Dari hasil analisis SPSS dengan uji Kruskal Wallis, didapatkan hubungan status penderita 
Tabel 1 Karakteristik Subjek Penelitian

\begin{tabular}{lc}
\hline \multicolumn{1}{c}{ Karakteristik } & $\mathbf{n = 9 3 6}$ \\
\hline Usia (median, rentang) & $29(17-65)$ \\
Jenis kelamin (n \%) & $653(69,8)$ \\
$\quad$ Pria & $283(30,2)$ \\
Wanita & \\
IMT (median, rentang) & $19.4(12,1-36,2)$ \\
IMT (kategori) & $526(56,2)$ \\
Underweight & $337(36)$ \\
Normoweight & $67(7,2)$ \\
Overweight & $6(0,6)$ \\
Obese & $151(1-1329)$ \\
CD4 (median, rentang) & \\
Tekanan darah & $110(90-180)$ \\
Sistol & $80(26-110)$ \\
Diastol & $157(52-382)$ \\
Kolesterol Total & $41(10-102)$ \\
HDL & $83(10-212)$ \\
LDL & $143(47-1519)$ \\
Trigliserida & $93(46-225)$ \\
Glukosa & \\
\hline & \\
\hline &
\end{tabular}

HIV dengan IMT mempunyai nilai $p=0,0001$ $(p<0,05)$, yang menunjukkan perbedaan ratarata (median) IMT antara penderita HIV yang meninggal, aktif berobat dan penderita yang ditransfer, dengan nilai median IMT berturutturut dari yang terendah sampai yang tertinggi pada penderita yang meninggal mempunyai nilai median IMT 17,5 (12,1-28,7), Aktif 19,3 (12,6$36,2)$, dan transfer 20,1 (12,3-32,4).

Hubungan status penderita HIV dengan CD4 memiliki nilai $p=0,0001(p<0,05)$ menunjukkan perbedaan rata-rata dari (median) CD4 antara penderita HIV yang meninggal, aktif berobat dan penderita yang transfer, dengan nilai median CD4 berturut-turut dari yang terendah sampai yang tertinggi: pada penderita yang meninggal mempunyai nilai median CD4 33 (1-970), aktif 157 (1-1329), dan transfer 214,5 (2-1275).

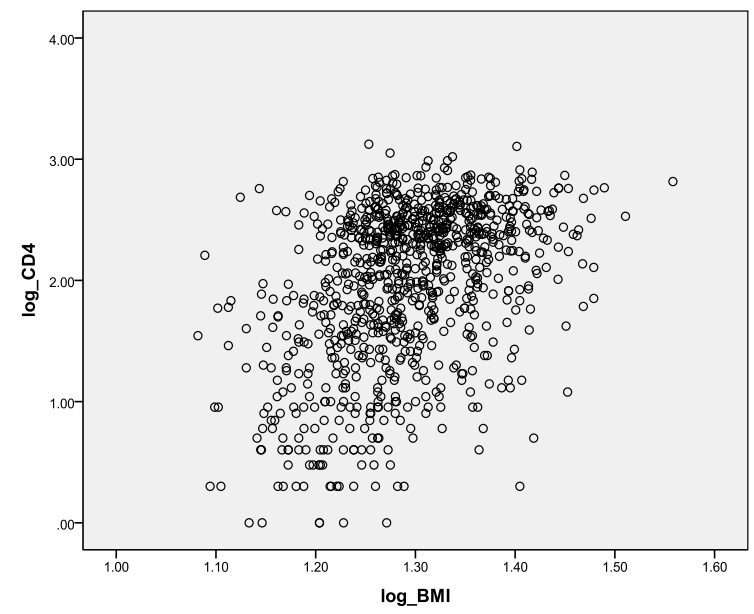

Gambar 1 Hubungan antara IMT dan CD4

\section{Pembahasan}

Peningkatan lemak tubuh, massa tubuh, atau keduanya dapat menghasilkan peningkatan dari IMT. Dari literatur disebutkan bahwa penurunan dari IMT berhubungan dengan prognosis yang lebih buruk pada penderita HIV. ${ }^{5}$ Hal tersebut dapat dijelaskan bahwa IMT berhubungan

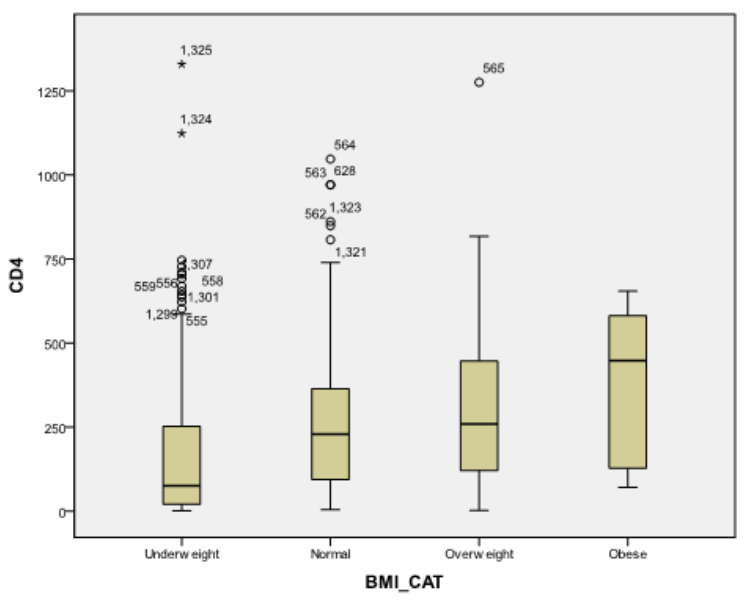

Gambar 2 Grafik Hubungan antara IMT dan CD4

Tabel 2 Hubungan IM dengan CD4

\begin{tabular}{cccccc}
\hline & $\begin{array}{c}\text { Underweight } \\
\mathbf{n = 5 2 6}\end{array}$ & $\begin{array}{c}\text { Normal } \\
\mathbf{n = 3 3 7}\end{array}$ & $\begin{array}{c}\text { Overweight } \\
\mathbf{n = 6 7}\end{array}$ & $\begin{array}{c}\text { Obese } \\
\mathbf{n = 6}\end{array}$ & $\mathbf{p}$ \\
\hline $\mathrm{CD} 4$ & $75(1-1329)$ & $229(4-1047)$ & $259(2-1275)$ & $447(71-654)$ & 0.0001 \\
\hline
\end{tabular}


Tabel 3 Hubungan Status Penderita HIV dengan IMT dan CD4

\begin{tabular}{ccccc}
\hline & $\begin{array}{c}\text { Meninggal } \\
\mathbf{n = 6 3}\end{array}$ & $\begin{array}{c}\text { Aktif } \\
\mathbf{n = 6 9 7}\end{array}$ & $\begin{array}{c}\text { Transfer } \\
\mathbf{n = 1 7 6}\end{array}$ & $\mathbf{p}$ \\
\hline IMT & $17.5(12,1-28,7)$ & $19,3(12,6-36,2)$ & $20,1(12,3-32,4)$ & 0,0001 \\
CD4 & $33(1-970)$ & $157(1-1329)$ & $214,5(2-1275)$ & 0,0001 \\
\hline
\end{tabular}

dengan status nutrisi penderita HIV, oleh karena status nutrisi tersebut sangat berpengaruh pada fungsi dan juga status imunitas pada penderita HIV. ${ }^{6}$ Penelitian ini berhubungan positif dengan CD4, hal ini sesuai dengan penelitian "The Miami Intravenous Drug Abuse Study/MIDAS" dan "The Nutrition for Healthy Living Study/NFHL".,4

Beberapa alasan atau mekanisme biologis yang dapat menjelaskan hasil yang didapatkan tersebut adalah (1) penderita HIV dengan jumlah CD4 yang rendah mempunyai kecenderungan penurunan berat badan atau (2) penderita HIV dengan beratbadan lebih dapatmempertahankan jumlah CD4-nya dalam level yang lebih tinggi, dengan penjelasan kemungkinan efek protektif sel lemak atau adiposa itu sendiri. Seperti telah diketahui bahwa sel lemak merupakan sumber hormon leptin yang bersirkulasi di dalam tubuh sejalan dengan jumlah atau komposisi sel lemak itu sendiri. ${ }^{7}$ Kadar leptin umumnya lebih tinggi pada wanita dibanding dengan pria. ${ }^{8,9}$ Kadar leptin memiliki kecenderungan untuk mengalami peningkatan pada saat fase akut infeksi. ${ }^{10}$

Sel CD4 mempunyai reseptor leptin yang dapat membantu sel CD4 berproliferasi sebagai respons terhadap berbagai stimulus. $^{11}$ Kadar leptin dapat ditemukan menurun secara akut pada keadaan starvasi/kelaparan dan juga pada keadaan defisiensi sistem imun. ${ }^{12,13}$

Pada binatang percobaan (tikus), Faggioni $\mathrm{dkk}^{14}$ mendapatkan hasil penurunan endotoxic shock pada tikus dengan starvasi yang diberikan lipopolisakarida, yaitu preparat leptin. Leptin merupakan sitokin helical rantai panjang dengan struktur yang menyerupai interleukin (IL)-6, IL11, IL-12, leukeumia inhibitory factor, granulocyte colony-stimulating factor, dan juga didapatkan kesamaan struktural antara reseptor leptin dan reseptor sitokin. Secara teoritis, leptin dapat menghambat efek merugikan/merusak sitokin yang kadarnya meningkat pada penderita HIV. ${ }^{10}$

Hubungan antara massa lemak dan jumlah CD4 dapat diterangkan dengan efek langsung sel lemak dan substrat yang dihasilkannya. Mekanisme ini perlu dipelajari lebih lanjut di masa yang akan datang. Walaupun didapatkan hubungan positif antara IMT dan CD4, temuan ini harus diinterpetasi dengan catatan karena pada penelitian ini merupakan penelitian potong lintang yang tidak menggambarkan hubungan utuh kedua variabel tersebut dan juga tidak menganalisis mekanisme biologis yang terjadi pada kedua variabel tersebut. Penelitian ini juga tidak memperhitungkan faktor-faktor lain yang dapat memengaruhi progresivitas HIV seperti status nutrisi, keteraturan kontrol ke pelayanan kesehatan, dan keteraturan minum obat (juga faktor-faktor lainnya).

Didapatkan bukti-bukti yang menunjukkan bahwa peningkatan IMT berhubungan dengan peningkatan jumlah CD4 yang menggambarkan penurunan perjalanan atau progresivitas HIV, walaupun efek protektif ini tidak disimpulkan secara holistik.

\section{Daftar Pustaka}

1. Shuter J, Chang CJ, Klein RS. Prevalence and predictive value of overweight in an urban HIV care clinic. J Acquir Immune Defic Syndr. 2006;26:291-7.

2. Amorosa V, Synnestvedt M, Gross R, Friedman $\mathrm{H}$, MacGregor RR, Gudonis D, dkk. A tale of 2 epidemics: the intersection between obesity and HIV infection in Philadelphia. J Acquir Immune Defic Syndr. 2005;39(5):557-61.

3. Shor-Posner G, Campa A, Zhang G, Persaud N, Miguez-Burbano MJ, Quesada J, dkk. When obesity is desirable: a longitudinal study of the Miami HIV-1-Infected Drug Abusers (MIDAS) cohort. J Acquir Immune Defic Syndr. 2006;23(1):81-8.

4. Tilg $\mathrm{H}$, Moschen AR. Adipocytokines: mediators linking adipose tissue, inflammation and immunity. Nat Rev Immunol. 2006;6:772-83.

5. Crum-Cianflone NF, Roediger M, Eberly LE, Vyas K, Landrum ML, Ganesan A, dkk. Infectious Disease Clinical Research Program HIV Working Group. Obesity among HIVinfected persons: impact of weight on CD4 cell count. AIDS. 2010;24(7):1069-72.

6. Bosch RJ, Bennett $\mathrm{K}$, Collier AC, Zackin $\mathrm{R}$, Benson CA. Pretreatment factors associated with 3-year (144-week) virologic 
and immunologic responses to potent antiretroviral therapy. J Acquir Immune Defic Syndr. 2007;44:268-77.

7. Smurzynski M, Collier AC, Koletar SL, Bosch RJ, Wu K, Bastow B, Benson CA. AIDS Clinical Trials Group longitudinal linked randomized trials (ALLRT): rationale, design, and baseline characteristics. HIV Clin Trials. 2008;9:26982.

8. Ostrowski S, Katzenstein T, Thim P, Pedersen B, Gerstoft J, Ullum H. Low-level viremia and proviral DNA impede immune reconstitution in HIV-1-infected patients receiving HAART. J Infect Dis. 2005;191(3):348-57.

9. Moore RD, Keruly JC. CD4+ cell count 6 years after commencement of highly active antiretroviral therapy in persons with sustained virologic suppression. Clin Infect Dis. 2007;44(3):441-6.

10. Nowicki MJ1, Karim R, Mack WJ, Minkoff $\mathrm{H}$, Anastos K, Cohen M, dkk. Correlates of CD4+ and CD8+ lymphocyte counts in high-risk immunodeficiency virus (HIV)seronegative women enrolled in the women's interagency HIV study (WIHS). Hum Immunol. 2007;68(5):342-9.

11. Womack J, Tien PC, Feldman J, Shin JH, Fennie K, Anastos K, dkk. Obesity and immune cell counts in women. Metabolism. 2007;56(7):998-1004

12. Zaldivar F, McMurray RG, Nemet D, Galassetti P, Mills PJ, Cooper DM. Body fat and circulating leukocytes in children. Int J Obes (Lond). 2006;30(6):906-11.

13. Fantuzzi G. Adipose tissue, adipokines, and inflammation. J Allergy Clin Immunol. 2005; 115:911-9.

14. Faggioni R, Moser A, Feingold KR, Grunfeld C. Reduced leptin levels in starvation increase susceptibility to endotoxic shock. Am J Pathol 2005;156:1781-7. 